\title{
Design, Synthesis, and Biological Evaluation of the Sex Pheromone of the Asian Corn Borer, Ostrinia furnacalis (Guenée)
}

\author{
Zhengchang Lu, ${ }^{1,2,3}$ Wei Liu $\mathbb{D}^{1},{ }^{1}$ Hongyu Pan, ${ }^{3}$ and Dawei Zhang $\mathbb{D}^{1}$ \\ ${ }^{1}$ College of Chemistry, Jilin University, Changchun 130012, China \\ ${ }^{2}$ School of Chemical Biology and Biotechnology, Peking University Shenzhen Graduate School, Shenzhen 518055, China \\ ${ }^{3}$ College of Plant Science, Jilin University, Changchun 130062, China \\ Correspondence should be addressed to Wei Liu; liuwei871016@sina.com and Dawei Zhang; z_dw@jlu.edu.cn
}

Received 23 October 2017; Revised 17 January 2018; Accepted 12 February 2018; Published 14 March 2018

Academic Editor: Beatriz Oliveira

Copyright (C) 2018 Zhengchang Lu et al. This is an open access article distributed under the Creative Commons Attribution License, which permits unrestricted use, distribution, and reproduction in any medium, provided the original work is properly cited.

\begin{abstract}
A convenient total synthesis of $(\boldsymbol{Z})$-12-tetradecenyl acetate (1a) and $(\boldsymbol{E})$-12-tetradecenyl acetate $(\mathbf{l b})$, which are the sex pheromones of Ostrinia furnacalis (Guenée), has been achieved. The target mixture molecules, of a cis-to-trans-isomer ratio of 27 to 73 , were synthesized in $40 \%$ overall yield and through $[13 \mathrm{C}+1 \mathrm{C}]$ synthetic strategy in five steps from commercially available and cheap industrial brassylic acid as key starting material. The electroantennogram (EAG) responses of synthetic sex pheromone to ACB male moths were conducted. The results showed that the target mixture molecules were found to have a good activity and displayed significantly stronger EAG responses ranging from 10 to $1000 \mu \mathrm{g}$, and the optimized stimulating dosage of the activity of synthetic sex pheromone to ACB males is $10 \mu \mathrm{g}$. Compared with the existing routes, this synthetic approach is operationally simple, goodyielding, and cost-effective, which could serve as a basis for developing the techniques of sex pheromone mass trapping or mating disruption and providing an environmentally benign method to control ACB pests.
\end{abstract}

\section{Introduction}

Ostrinia furnacalis (Guenée), often called the Asian Corn Borer (ACB), is the most destructive pest in corn throughout east and southeast Asian countries [1,2]. The larvae seriously damage corn, millet, sorghum, and cotton by boring through the stem that can eventually cause great yield losses $[3,4]$. Thus, the development of the effective method to control $A C B$ pests has been a very significant and practical question in the field of agriculture. Unfortunately, we are facing a big challenge caused by the detrimental effects, such as environmental pollution and pesticide residue, resulting from traditional chemical pesticide. Therefore, there is an urgent need to develop the environmentally friendly methods to control this pest. Among these known modes, such as chemical, biological, or physical pest control, it is an ideal way to control $\mathrm{ACB}$ pests by using the sex pheromone mass trapping or mating disruption, because it has the characteristics of being of low cost, environmentally friendly, of low dosage, of strong selectivity, and of high sensitivity [5-9].

The sex pheromone of ACB, released by adult females, is a mixture of $(Z)$-12-tetradecenyl acetate (1a) and (E)-12tetradecenyl acetate (1b) (Figure 1) [10-12].

To date, some strategies have been developed for synthesizing the sex pheromone of the ACB. These existing strategies focused on the carbon chain increasing or decreasing to construct the main chain. Based on the carbon chain increasing synthetic strategies [13], these include Klun et al. who realized the synthesis of $\mathbf{1 a}$ and $\mathbf{1 b}$ firstly using $[7 \mathrm{C}+$ $1 \mathrm{C}+6 \mathrm{C}]$ synthetic strategy [10]. Kang et al. adopted the $[11 C+2 C+1 C]$ synthetic strategy and synthesized the sex pheromone monomers with two different constructions by using triple-bond cis-trans hydrogenation [14]. The products of the above two routes required subsequent mixing before field application. As $[12 \mathrm{C}+2 \mathrm{C}]$ synthetic strategy, the 1,12dodecanediol was used to design the synthesis as identical 


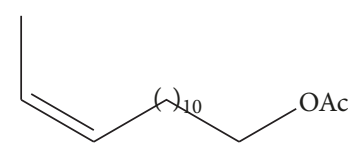

(Z)-12-Tetradecenyl acetate 1a

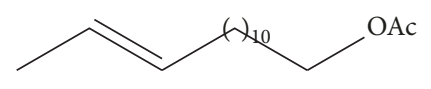

(E)-12-Tetradecenyl acetate

$\mathbf{1 b}$

FIgURE 1: Chemical structure of the sex pheromone of ACB.

Prior work:<smiles>C#CC[AlH2]CO[InH2]</smiles>

$[7 C+1 C+6 C]$<smiles>C=CCCOC(C)=O</smiles>

$[11 C+3 C]$<smiles>[PH2+]C[14CH2]CBr</smiles>

$[11 C+2 C+1 C]$<smiles>OC[14CH2]CO</smiles>

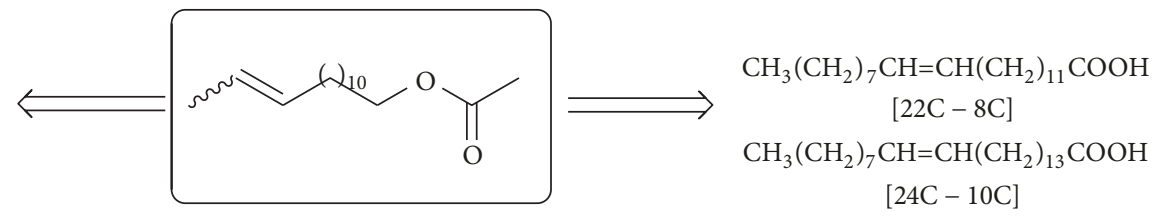

1a, $1 b$

$[12 \mathrm{C}+2 \mathrm{C}]$

This work:

$\mathrm{HOOC}_{\mathrm{H}_{9}} \mathrm{COOH}$

$[13 \mathrm{C}+1 \mathrm{C}]$

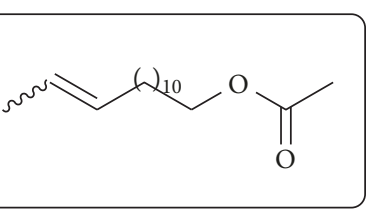

$1 a, 1 b$

Scheme 1: Comparison between the existing literature synthetic strategies and this work.

starting material by some researchers, including Kang et al. [14] and Chen et al. in $60 \%$ or $32 \%$ overall yield $[15,16]$, Chen and Du in $45 \%$ overall yield [17], and Li et al. in $36.6 \%$ overall yield [18]. Adopting [11C $+3 \mathrm{C}]$ synthetic strategy, Li and Schwarz synthesized the olefins through the "one-pot" reaction of borane reagents by using hydroboration in $18 \%$ overall yield [19]. In contrast, based on the carbon chain decreasing synthetic strategies, as [22C - 8C] and [24C 10C] synthetic strategy, Wang and Liu synthesized the target mixture molecules in $15 \%$ overall yield from natural available $Z$-13-docosenoic acid [20]. Liu et al. reported a synthetic route in $17.5 \%$ overall yield from the unsaturated fatty acid $Z$ 15-tetracosenic acid as starting material [21] (Scheme 1, top).

In spite of many advantages, the existing synthetic routes have some drawbacks, such as requiring too many steps, lower overall yields, lack of cost-effectiveness, or separate components preparation process, which required subsequent mixing before field application. Therefore, the development of the cost-effective and operationally simple synthetic strategy for the sex pheromone of ACB is still of great interest in agrochemicals.
Herein, we describe a new $[13 \mathrm{C}+1 \mathrm{C}]$ synthetic strategy for the sex pheromone of ACB from commercially available and cheap industrial brassylic acid as key starting material (Scheme 1, bottom). The target mixture molecules, where the cis-trans-isomer (1a and $\mathbf{1 b}$ ) ratio is 27 to 73 , were synthesized in $40 \%$ overall yield and in five steps through the operationally simple and economical approaches. EAG assays were conducted to verify the biological activity to ACB male moth and obtain the optimum stimulating dosage of the sex pheromone.

\section{Results and Discussion}

2.1. Chemistry. As shown in Scheme 2, our synthesis commenced with brassylic acid 2, which is a commercially available and cheap industrial material. After carboxyl reduction and selective esterification, compounds 3 and 4 were smoothly obtained. However, in attempts to purify compound 3 in the laboratory, this was found to be very laborious and less effective, so crude 3 was directly treated with glacial acetic acid in cyclohexane under concentrated sulfuric acid 


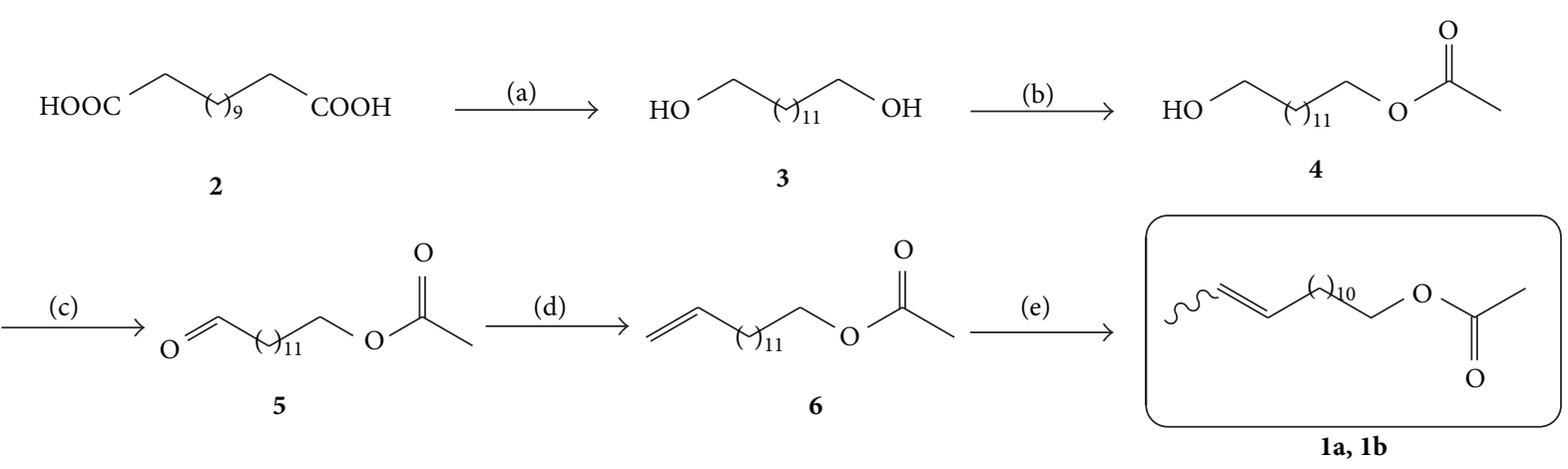

Reagents and conditions: (a) $\mathrm{LiAlH}_{4}$, THF, $\mathrm{N}_{2}$, r.t.; (b) $\mathrm{AcOH}, \mathrm{C}_{6} \mathrm{H}_{12}, 98 \% \mathrm{H}_{2} \mathrm{SO}_{4}$ (cat.), $55^{\circ} \mathrm{C}, 65 \%$ for two steps; (c) PCC, DCM, r.t., $95 \%$; (d) $\mathrm{CH}_{3} \mathrm{PPh}_{3} \mathrm{Br}$, t-BuOK, THF, $\mathrm{N}_{2}$, r.t., and then $-20^{\circ} \mathrm{C}, 86 \%$; (e) $\mathrm{CoCl}_{2}, \mathrm{Ph}_{3} \mathrm{P}, \mathrm{NaBH}_{4}, \mathrm{~N}_{2}$, r.t., and then $-10^{\circ} \mathrm{C}, 76 \%$, GC-MS $1 \mathrm{a}: 1 \mathrm{~b}=27: 73$

SCHEme 2: Synthesis of the target compounds.

catalysis at $55^{\circ} \mathrm{C}$. Thus compound 4 was obtained in $65 \%$ yield over two steps. Compound 5 was prepared in $95 \%$ yield in $\mathrm{CH}_{2} \mathrm{Cl}_{2}$ at room temperature from compound 4 through PCC oxidation reported by Boo [11]. Afterwards, the key intermediate $\mathbf{6}$ was obtained by the Wittig condensation; the 13-oxotridecyl acetate 5 was coupled with methyltriphenylphosphonium bromide under potassium tert-butylate catalysis in $86 \%$ yield. The target molecules were produced through isomerization reaction by $\mathrm{CoCl}_{2}-\mathrm{Ph}_{3} \mathrm{P}-\mathrm{NaBH}_{4}$ system from compound $\mathbf{6}$ under nitrogen atmosphere at room temperature and then $-10^{\circ} \mathrm{C}$ in $76 \%$ yield. Additionally, the configurations of the target were assigned on the basis of the ${ }^{1} \mathrm{H}-\mathrm{NMR},{ }^{13} \mathrm{C}-\mathrm{NMR}$, and MS spectroscopy. The ratio of cis isomer to trans isomer is 27 to 73 , which was further confirmed by the GC-MS data and the comparison with analysis results of related reports, such as Kou et al.s work [22]. More information can be found in the supplementary materials (available here)

Overall, a convenient synthesis route for the sex pheromone of the O. furnacalis was developed through $[13 \mathrm{C}+1 \mathrm{C}]$ strategy of brassylic acid and methyltriphenylphosphonium bromide. Thus, the total synthesis of the mixture $\mathbf{1 a}$ and $\mathbf{1 b}$, where the cis-trans-isomer ratio is 27 to 73 , in $40 \%$ overall yield has been achieved in five steps. Compared with other reported synthesis of the target, our synthesis by using readily available inexpensive reagents and simple reaction conditions is apparently operationally simple and cost-effective.

2.2. Biological Activity. Electroantennogram (EAG) technology, which is based on the discovery by Schneider [23], is a bioassay widely used in experimental entomology for the detection of volatiles perceived by the antennal olfactory apparatus of insects. This method can be used for many purposes like screening biologically active compounds, purification of extracts, identification of active fractions, selection of active synthetic compounds, and so on.

In order to screen the biological activity of the attractiveness of synthetic sex pheromone molecules to ACB male

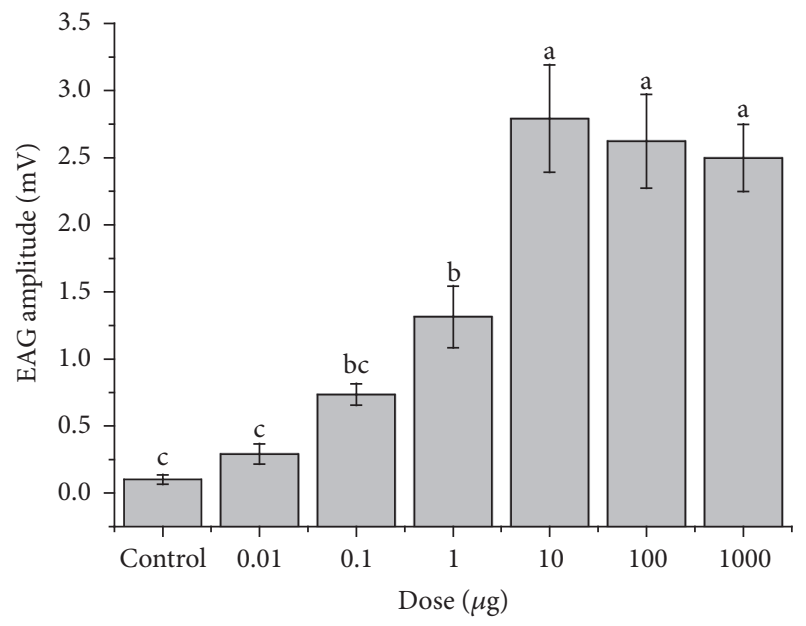

FIGURE 2: Electroantennogram responses $[\mathrm{mV} \pm \mathrm{SE}$ (standard error)] of ACB male moths to binary blends of the ratio $27: 73(Z: E)$ in different doses. Male moths treated with $1 \mu \mathrm{L}$ of redistilled hexane were used as control. Bars with the same letter are not significantly different (ANOVA and Tukey's HSD, $p<0.05$ ).

moths, the EAG assays were performed. The results are shown in Figure 2.

The results showed that there was a relationship between EAG response and dose. At doses ranging from 1 to $1000 \mu \mathrm{g}$, the EAG responses values were significantly higher than the value of control. And there was no significant difference in EAG response values at doses $0.01 \mu \mathrm{g}$ and $0.1 \mu \mathrm{g}$ compared to the value of control. The results showed that the compounds had good biological activity within a broad range of doses (1 to $1000 \mu \mathrm{g}$ ) and low biological activity at the dose of $0.01 \mu \mathrm{g}$ and $0.1 \mu \mathrm{g}$. Among all doses tested, the optimal doses of compounds for EAG responses of O. furnacalis male moths were within 10 to $1000 \mu \mathrm{g}$ range, and the values were significantly different from the doses from 0.01 to $1 \mu \mathrm{g}$, and the highest response was reached at the dose $10 \mu \mathrm{g}$. The results 
suggested that the saturation dose of perception for males was $10 \mu \mathrm{g}$. On the base of these results, we conclude that the doses of compounds for the significantly stronger EAG responses of O. furnacalis male moths were in the range of 10 to $1000 \mu \mathrm{g}$, and the optimized stimulating dosage of the activity of sex pheromone to ACB male moths is $10 \mu \mathrm{g}$.

The cis-trans-isomer ratio of sex pheromone of the ACB is diverse in different areas of Asia [13], for example, $47: 53$ [24] or 42:32 [25] in China, 3:1 [26] or 39:45 in Taiwan [22], $1: 1$ in Philippines [10], 3:2 in Japan [27], and 1:1 in South Korea [11]. Cheng et al. reported that the maximum sexual attractiveness of the sex pheromone of ACB was reached within a rather broad range of doses $(0.1$ to $10 \mu \mathrm{g}$ per trap) at natural ratio of $47: 53(Z: E)$ in field trapping tests [24]. Zhou and Du reported that males responded in the highest percentage to doses between $0.1 \mu \mathrm{g}$ and $1 \mu \mathrm{g}$ of the sex pheromone at the ratio of $1: 1(Z: E)$ in wind tunnel tests [28]. However, in this study, the result suggested that significant EAG responses were reached within a broad range of doses $(10$ to $1000 \mu \mathrm{g})$ at the ratio of $27: 73(\boldsymbol{Z}: \boldsymbol{E})$ in EAG tests.

Generally, the EAG responses of synthetic sex pheromone to ACB male moths were observed. The results showed that the target mixture molecules, where the cis-trans-isomer ratio is 27 to 73 , were found to have a good activity and displayed significantly stronger EAG responses ranging from 10 to $1000 \mu \mathrm{g}$, and the optimum stimulating dosage of the biological activity of sex pheromone to ACB male moth is $10 \mu \mathrm{g}$. The results could serve as basis for developing the techniques of sex pheromone mass trapping or mating disruption techniques and providing an environmentally benign way to control ACB pests.

\section{Experimental}

\subsection{Chemistry}

3.1.1. General. All reagents were commercial and used without further purification. Tetrahydrofuran (THF) was freshly distilled from lithium aluminium hydride under a nitrogen atmosphere. Chromatography was carried on flash silica gel (300-400 mesh). All reactions were monitored by TLC, which was performed on precoated aluminium sheets of silica gel 60 (F254). Melting points were uncorrected. The ${ }^{1} \mathrm{H}$-NMR and ${ }^{13} \mathrm{C}$-NMR spectra were determined at $25^{\circ} \mathrm{C}$ at $500 \mathrm{MHz}$ and $125 \mathrm{MHz}$, respectively, with TMS as an internal standard. All shifts are given in ppm. High-resolution mass spectra (HRMS) were obtained using a Bruker microTOF II focus spectrometer (ESI). Gas chromatographic-mass spectrometric (GC-MS) analysis was conducted using an Agilent 5975 spectrometer. The GC-MS data were obtained using a $30 \mathrm{~m} \times 0.25 \mathrm{~mm}$ column of DB-1701 phase. The column temperature was run from 120 to $260^{\circ} \mathrm{C}$ at $3^{\circ} \mathrm{C} / \mathrm{min}$ and held at $260^{\circ} \mathrm{C}$ for $5 \mathrm{~min}$ using helium as carrier gas. Electron impact (EI) mass spectra were collected at $70 \mathrm{eV}$ with separator and source at $180^{\circ} \mathrm{C}$. EAG Systems (Syntech, Dutch) include Syntech IDAC-2 Acquisition Controller and Software, Syntech CS-55 Stimulus Controller Unit, Syntech Pre-Amplifier for Recording from Taste Sensilla, and Syntech MP-15 Micromanipulator.
3.1.2. Synthesis of 1,13-Tridecanediol (3). To a solution of brassylic acid $(2,1.2210 \mathrm{~g}, 5 \mathrm{mmol})$ in anhydrous THF $(15 \mathrm{~mL}), \mathrm{LiAlH}_{4}(0.5690 \mathrm{~g}, 15 \mathrm{mmol})$ was added in dry threenecked round-bottomed flask equipped in batches under nitrogen atmosphere at $0^{\circ} \mathrm{C}$. The mixture was stirred at room temperature for $12 \mathrm{~h}$. After completion, the reaction was quenched by $10 \% \mathrm{HCl}$ aqueous solution in ice bath until gas production ceased. The organic layer was separated, filtered, and concentrated under reduced pressure. The residue was washed with ethyl acetate and dried over anhydrous $\mathrm{MgSO}_{4}$. The extract was evaporated and dried to give crude 1,13tridecanediol $(3,1.0818 \mathrm{~g})$ as white solid. ${ }^{1} \mathrm{H}-\mathrm{NMR}\left(\mathrm{CDCl}_{3}\right.$, $500 \mathrm{MHz}) \delta 3.61(\mathrm{dd}, J=11.0,6.2 \mathrm{~Hz}, 4 \mathrm{H}), 2.35(\mathrm{~s}, 1 \mathrm{H})$, $2.26(\mathrm{~s}, 1 \mathrm{H}), 1.62-1.50(\mathrm{~m}, 4 \mathrm{H}), 1.39-1.20(\mathrm{~m}, 18 \mathrm{H}) ;{ }^{13} \mathrm{C}-\mathrm{NMR}$ $\left(\mathrm{CDCl}_{3}, 125 \mathrm{MHz}\right) \delta 77.2,77.0,76.7,32.6(2), 29.5(3), 29.4(2)$, 29.3(2), 25.6; HRMS (ESI-TOF) $m / z$ : Calcd. for $\mathrm{C}_{13} \mathrm{H}_{29} \mathrm{O}_{2}{ }^{+}$ 217.2183 $\left([\mathrm{M}+\mathrm{H}]^{+}\right)$. Found: 217.2205.

3.1.3. Synthesis of 13-Hydroxytridecyl Acetate (4). Glacial acetic acid $(23 \mathrm{~mL})$, water $(30 \mathrm{~mL})$, and concentrated sulfuric acid $(0.08 \mathrm{~mL})$ were added to a solution of crude $3(1.0818 \mathrm{~g})$ in cyclohexane $(40 \mathrm{~mL})$ successively in round flask. The mixture was stirred at $55^{\circ} \mathrm{C}$ for $10 \mathrm{~h}$. The reaction mixture was filtered, and the organic layer was washed successively with saturated $\mathrm{NaHCO}_{3}$ aqueous solution $(2 \times 20 \mathrm{~mL})(2 \times 20 \mathrm{~mL})$ and saturated salt water $(2 \times 20 \mathrm{~mL})$ and concentrated under reduced pressure. The residue was purified by flash column chromatography on silica gel (petroleum ether : diethyl ether $=3: 1)$ to provide pure 13-hydroxytridecyl acetate $(4,0.8398 \mathrm{~g}$, $65 \%$ for two steps) as a white solid. b.p. $49-50^{\circ} \mathrm{C},{ }^{1} \mathrm{H}-\mathrm{NMR}$ $\left(\mathrm{CDCl}_{3}, 500 \mathrm{MHz}\right) \delta 4.05(\mathrm{t}, J=6.8 \mathrm{~Hz}, 2 \mathrm{H}), 3.63(\mathrm{t}, J=$ $6.6 \mathrm{~Hz}, 2 \mathrm{H}), 2.17(\mathrm{~s}, 1 \mathrm{H}), 2.04(\mathrm{~s}, 3 \mathrm{H}), 1.66-1.52(\mathrm{~m}, 4 \mathrm{H})$, $1.40-1.20(\mathrm{~m}, 18 \mathrm{H}) ;{ }^{13} \mathrm{C}-\mathrm{NMR}\left(\mathrm{CDCl}_{3}, 125 \mathrm{MHz}\right) \delta 171.4,64.8$, 63.1, 32.9, 29.7(2), 29.6(2), 29.5, 29.3, 28.7, 26.0, 25.9, 21.1; HRMS (ESI-TOF) $m / z$ : Calcd. for $\mathrm{C}_{15} \mathrm{H}_{31} \mathrm{O}_{3}{ }^{+} 259.2107$ ([M $+\mathrm{H}]^{+}$). Found: 259.2203

3.1.4. Synthesis of 13-Oxotridecyl Acetate (5). Compound 4 $(0.5168 \mathrm{~g}, 2 \mathrm{mmol})$ was added to a solution of PCC $(0.6466 \mathrm{~g}$, $3 \mathrm{mmol}$ ) in dichloromethane (DCM, $15 \mathrm{~mL}$ ) in a round flask in batches at room temperature. The mixture was stirred and monitored by TLC. After substrate 4 was consumed, the resulting mixture was poured into ice-water $(30 \mathrm{~mL})$ while stirring. The solid was collected by filtration, washed with water $(3 \times 10 \mathrm{~mL})$, and dried and purified by flash column chromatography on silica gel (petroleum ether : diethyl ether $=8: 1)$ to give 13 -oxotridecyl acetate $(5,0.4867 \mathrm{~g}, 95 \%)$ as a white solid. b.p. $24-26^{\circ} \mathrm{C},{ }^{1} \mathrm{H}-\mathrm{NMR}\left(\mathrm{CDCl}_{3}, 500 \mathrm{MHz}\right) \delta$ $9.76(\mathrm{t}, J=1.8 \mathrm{~Hz}, 1 \mathrm{H}), 4.05(\mathrm{t}, J=6.8 \mathrm{~Hz}, 2 \mathrm{H}), 2.42(\mathrm{td}$, $J=7.4,1.8 \mathrm{~Hz}, 2 \mathrm{H}), 2.04(\mathrm{~s}, 3 \mathrm{H}), 1.67-1.57$ (m, 4H), 1.41-1.19 $(\mathrm{m}, 16 \mathrm{H}) ;{ }^{13} \mathrm{C}-\mathrm{NMR}\left(\mathrm{CDCl}_{3}, 125 \mathrm{MHz}\right) \delta 202.9,171.3,64.7$, 43.9, 29.6, 29.5(2), 29.4, 29.2(2), 28.6, 26.0, 22.1, 21.0; HRMS (ESI-TOF) $m / z$ : Calcd. for $\mathrm{C}_{15} \mathrm{H}_{29} \mathrm{O}_{3}{ }^{+} 257.2801\left([\mathrm{M}+\mathrm{H}]^{+}\right)$. Found: 257.3901.

3.1.5. Synthesis of 13-Tetradecenyl Acetate (6). Potassium tert-butoxide $(0.2244 \mathrm{~g}, 2 \mathrm{mmol})$ was added to a solution of methyltriphenylphosphonium bromide $(0.7144 \mathrm{~g}$, $2 \mathrm{mmol})$ in anhydrous THF $(10 \mathrm{~mL})$ in dry three-necked 
round-bottomed flask under a nitrogen atmosphere at room temperature. The mixture was stirred for $30 \mathrm{~min}$. At $-20^{\circ} \mathrm{C}$, compound 5 (0.3074 g, $1.2 \mathrm{mmol})$ was dissolved in anhydrous THF $(5 \mathrm{~mL})$ in dry batches under a nitrogen atmosphere; then the resulting solution was introduced through a dropping funnel to the above mixture at this temperature (approx. $5 \mathrm{~min}$ ). The reaction mixture was stirred and monitored by TLC. After substrate 5 was consumed, the reaction mixture was quenched by saturated $\mathrm{NH}_{4} \mathrm{Cl}$ aqueous solution $(20 \mathrm{ml})$ and extracted with diethyl ether $(2 \times 10 \mathrm{~mL})$, and the organic layer was combined. After evaporating the solvent, the residue was purified by flash column chromatography on silica gel (petroleum ether : diethyl ether $=10: 1$ ) to give 13 tetradecenyl acetate $(6,0.2623 \mathrm{~g}, 86 \%)$ as a yellow oil. ${ }^{1} \mathrm{H}$ $\mathrm{NMR}\left(\mathrm{CDCl}_{3}, 500 \mathrm{MHz}\right) \delta 5.86-5.76(\mathrm{~m}, 1 \mathrm{H}), 5.02-4.96(\mathrm{~m}$, $1 \mathrm{H}), 4.95-4.96(\mathrm{~m}, 1 \mathrm{H}), 4.05(\mathrm{t}, J=6.8 \mathrm{~Hz}, 2 \mathrm{H}), 2.04(\mathrm{~s}, 3 \mathrm{H})$, $1.66-1.57(\mathrm{~m}, 4 \mathrm{H}), 1.32-1.25(\mathrm{~m}, 18 \mathrm{H}) ;{ }^{13} \mathrm{C}-\mathrm{NMR}\left(\mathrm{CDCl}_{3}\right.$, $125 \mathrm{MHz}) \delta 171.4,139.4,114.2,64.8,33.9,29.7(3), 29.6(2), 29.4$, 29.2, 29.1, 28.7, 26.1, 21.2; HRMS (ESI-TOF) $\mathrm{m} / z$ : Calcd. for $\mathrm{C}_{16} \mathrm{H}_{31} \mathrm{O}_{2}{ }^{+} 255.2189\left([\mathrm{M}+\mathrm{H}]^{+}\right)$. Found: 255.2301 .

3.1.6. Synthesis of $(\mathbf{Z} / \mathbf{E})$-12-Tetradecene-1-ol Acetate $(\mathbf{1 a} / \mathbf{1 b})$. Cobalt dichloride $(0.2855 \mathrm{~g}, 1.2 \mathrm{mmol})$ was dried at $135^{\circ} \mathrm{C}$ under vacuum for $8 \mathrm{~h}$. After cooling to room temperature, triphenylphosphine $(0.9442 \mathrm{~g}, 3.6 \mathrm{mmol})$ was added to a solution of the anhydrous cobalt dichloride in anhydrous THF $(10 \mathrm{~mL})$ in dry three-necked round-bottomed flask under a nitrogen atmosphere at room temperature. After stirring for $30 \mathrm{~min}$, sodium borohydride $(0.0454 \mathrm{~g}, 1.2 \mathrm{mmol})$ was added to the mixture and then stirred for $30 \mathrm{~min}$. Compound $6(0.4677 \mathrm{~g}, 1.84 \mathrm{mmol})$ was dissolved in anhydrous THF $(5 \mathrm{~mL})$; the resulting solution was added dropwise to the above mixture at $-10^{\circ} \mathrm{C}$. The mixture was stirred for $4 \mathrm{~h}$ till the reaction was completed. Then $2 \mathrm{~mol} / \mathrm{L} \mathrm{HCl}(10 \mathrm{~mL})$ was added to the mixture, and the reaction mixture was extracted with diethyl ether $(2 \times 10 \mathrm{~mL})$ and then condensed under reduced pressure to give crude product. The residue was purified by flash column chromatography on silica gel (petroleum ether: diethyl ether $=10: 1$ ) to give the mixture of $(Z / E)$-12-tetradecene-1-ol acetate $(\mathbf{1 a}, \mathbf{1 b}, 0.3555 \mathrm{~g}, 76 \%$, GC-MS, $\mathbf{1 a}: \mathbf{1 b}=27: 73)$ as a yellow oil. ${ }^{1} \mathrm{H}-\mathrm{NMR}\left(\mathrm{CDCl}_{3}\right.$, $500 \mathrm{MHz}) \delta 5.38-5.41(\mathrm{~m}, 2 \mathrm{H},-\mathrm{CH}=\mathrm{CH}-), 4.02(\mathrm{t}, J=6.6 \mathrm{~Hz}$, $2 \mathrm{H}, \mathrm{CH}_{2} \mathrm{OAc}$ ), 2.03 (s, 3H, $\mathrm{COCH}_{3}$ ), 2.03 (d, 3H, $\mathrm{CH}_{3} \mathrm{C}=$ ), $1.64\left(\mathrm{~m}, 4 \mathrm{H}, \mathrm{CH}_{2}\right), 1.26-1.32\left(\mathrm{~m}, 16 \mathrm{H}, 8 \mathrm{CH}_{2}\right) ;{ }^{13} \mathrm{C}-\mathrm{NMR}$ $\left(\mathrm{CDCl}_{3}, 125 \mathrm{MHz}\right) \delta 171.3,131.9,131.7,130.9,129.4,124.6,123.7$, 64.78, 32.7, 32.6, 29.7(3), 29.6(2), 29.4, 29.3(2), 29.2 , 28.7, 26.9, 26.0, 25.7, 21.1, 18.0, 14.1, 12.8; HRMS (ESI-TOF) $m / z$ : Calcd. for $\mathrm{C}_{16} \mathrm{H}_{31} \mathrm{O}_{2}{ }^{+} 255.2189\left([\mathrm{M}+\mathrm{H}]^{+}\right)$. Found: 255.2301 .

\subsection{Biological Tests}

3.2.1. Chemicals. The sex pheromones, which were synthesized and purified as presented in Scheme 1, were diluted to make $1000 \mu \mathrm{g} / \mu \mathrm{L}$ with redistilled hexane. Further serial 10 times' dilutions were made to obtain different concentrations ranging from $0.01 \mu \mathrm{g} / \mu \mathrm{L}$ to $100 \mu \mathrm{g} / \mu \mathrm{L}$ for EAG assays.

3.2.2. Insect. Live O. furnacalis pupae were provided by Beijing Academy of Agricultural and Forestry Sciences. Pupae were sexed, and males were placed in small plastic boxes $(5 \mathrm{~cm} \times 5 \mathrm{~cm})$ individually and maintained in a climatic chamber on a $16: 8 \mathrm{~h}$ light: dark regime at $25 \pm 1^{\circ} \mathrm{C}$ and $70 \pm 10 \%$ relative humidity. After emergence, male adults were provided with $10 \%$ sucrose solution, separated daily by age, and kept on filter paper in plastic containers.

3.2.3. EAG Assays [29]. Two-day-old Asian Corn Borer males were slightly anaesthetized with ice for $2 \mathrm{~min}$, followed by $1 \mathrm{~min}$ at room temperature to allow males to recover, and then they were immobilized with an insect pin. Antennae were excised from head with forceps and their last segments were cut with forceps. The antennae were then fixed to the electrodes with conducting gel Spectra 360 (Parker Lab. Inc., Hellendoorn, Netherlands). A flow of humidified pure air $(1200 \mathrm{~mL} / \mathrm{min})$ was continuously directed over the male antenna through the main branch of a glass tube $(7 \mathrm{~cm}$ long $\times 5 \mathrm{~mm}$ diameter). Test stimulations were performed by giving puffs of air $(500 \mathrm{~mL} / \mathrm{min})$ for $0.5 \mathrm{~s}$ at $30 \mathrm{~s}$ intervals through a Pasteur pipette inserted onto a lateral branch of the tube, using a CS-55 stimulus controller (Syntech). The pipette contained a piece of filter paper $(5 \times 0.5 \mathrm{~cm})$ on which the stimulus compound had been deposited. The solvent was evaporated before the tests. Control puffs over a piece of filter paper containing only hexane were intercalated between two consecutive stimuli. The signals were amplified (100x) and filtered (DC to $1 \mathrm{kHz}$ ) with an IDAC-2 interface (Syntech), digitized on a PC, and analyzed with the EAG Pro program. Each treatment was replicated on 6 antennae; the experiment was repeated three times [30].

3.2.4. Statistical Analysis. EAG recordings were obtained from six antennal preparations for each treatment. For analyses, EAG response to the solvent control was deducted from the EAG amplitudes elicited by the test compounds. The corrected EAG data were analyzed by analysis of variance (ANOVA) followed by Tukey's HSD test $(p<0.05)$, using PASW Statistics 18.0.

\section{Conclusions}

In summary, we have developed a new and practical route for the total synthesis of the sex pheromones of $O$. furnacalis, using commercially available and cheap industrial brassylic acid as key starting material. Compared with the reported syntheses, this route has several advantages, such as good yield, simple operation, and cost-effectiveness. The EAG responses of synthetic sex pheromone to ACB male moths were conducted to verify the biological activity, and the results showed that the target mixture molecules, with the cis-trans-isomer ratio of 27 to 73 , have a good activity and displayed significantly stronger EAG responses from 10 to $1000 \mu \mathrm{g}$, and the optimized stimulating dosage of the attractive activity of sex pheromone to ACB male moth is $10 \mu \mathrm{g}$. This study may be helpful to develop a new route for large scale preparation of sex pheromone of $\mathrm{ACB}$ and provide an environmentally friendly method to control this pest in the future. 


\section{Conflicts of Interest}

The authors declare that they have no conflicts of interest.

\section{Authors' Contributions}

Zhengchang Lu and Wei Liu contributed equally to this work.

\section{Acknowledgments}

Financial support of this research provided by Science and Technology Planning Project of Jilin Province (20140204022NY, 20160414015GH, 20160414028GH, and 20180201012NY) and National Science \& Technology Pillar Program during the Thirteenth Five-Year Plan Period (2016YFD0300704 and 2017YFD0201802) is greatly acknowledged. The authors thank Fan Zhang and Su Wang from Beijing Academy of Agricultural and Forestry Sciences, Beijing, for providing EAG setup and O. furnacalis pupae.

\section{Supplementary Materials}

Copies of NMR spectra for compounds tridecane-1,13-diol (3), 13-hydroxytridecyl acetate (4), 13-oxotridecyl acetate (5), tetradec-13-en-1-yl acetate (6), and (Z/E)-12-tetradecene-1-ol acetate $(1 \mathrm{a}, 1 \mathrm{~b})$. Copies of MS spectra for compounds la and $1 \mathrm{~b},(\mathrm{Z} / \mathrm{E})-12$-tetradecene-1-ol acetate $(\mathrm{la}, \mathrm{bb})$. Analysis of the ratio of $(\mathrm{Z} / \mathrm{E})$-12-tetradecene-1-ol acetate (1a, 1b). Figure A: GC-MS analysis of the gonad extract of Asian Corn Borer [22]. Table 1: retention time of the gonad extract of Asian Corn Borer [22]. Figure B: GC-MS analysis of the sex pheromone of Asian Corn Borer. Table 2: retention time of the sex pheromone of Asian Core Borer. (Supplementary Materials)

\section{References}

[1] Z. Y. Wang, X. Lu, K. L. HE, and D. R. Zhou, "Review of history, present situation and prospect of the Asian maize borer research in China," Journal, vol. 10, pp. 402-412, 2000.

[2] D. M. Nafus and I. H. Schreiner, "Review of the biology and control of the Asian corn borer, ostrinia furnacalis (lep: Pyralidae)," International Journal of Pest Management, vol. 37, no. 1, pp. 41-56, 1991.

[3] Z. C. Wang, H. I. Qian, H. Dong, J. H. Wang, and Z. Y. Wang, "Studies on the damage degree and yield loss by Asian corn borer," Plant Protection, vol. 34, pp. 112-115, 2008.

[4] S. X. Zhou, X. Lu, L. J. Li, G. H. Zhang, Y. Ding, and X. Chang, "Study on the corn yield loss damaged by the second generation of Asian corn borer, Ostrinia furnacalis (Guenée)," Chinese Journal of Applied Entomology, vol. 51, pp. 676-679, 2014.

[5] S. L. Liu, Z. F. Su, H. W. Wang, and X. J. Ma, "Effects of trap device type and dosage of different sex attractants on the trapping efficacy of Ostrinia furnacalis," Journal of Anhui Agricultural Sciences, vol. 44, pp. 93-94, 2016.

[6] D. H. Hu, X. W. Yang, D. Han, and H. Wang, "Study on the trapping effects and field application of different sex attractants against Ostrinia furnacalis," Chinese Journal of Pesticide Science, vol. 17, pp. 101-105, 2015.

[7] Y. Z. Wang, Z. Y. Wang, R. Sheng et al., "Field trapping efficacy of two types of sex pheromone lures on the Asian corn borer," Plant Protection, vol. 39, pp. 173-174, 2013.
[8] R.-Z. Chen, L.-B. Li, M. G. Klein, Q.-Y. Li, P.-P. Li, and C.F. Sheng, "Captures of ostrinia furnacalis (lepidoptera: Crambidae) with sex pheromone traps in NE China Corn and Soybeans," Environmental Entomology, vol. 45, no. 1, pp. 207215, 2016.

[9] R.-Z. Chen, M. G. Klein, C.-F. Sheng, Y. Li, D.-X. Shao, and Q.$\mathrm{Y}$. Li, "Use of pheromone timed insecticide applications integrated with mating disruption or mass trapping against ostrinia furnacalis (Lepidoptera: Pyralidae) in sweet corn," Environmental Entomology, vol. 42, no. 6, pp. 1390-1399, 2013.

[10] J. A. Klun, B. A. Bierl-Leonhardt, M. Schwarz et al., "Sex pheromone of the Asian corn borer moth," Life Sciences, vol. 27, no. 17, pp. 1603-1606, 1980.

[11] K. S. Boo, "Variation in Sex Pheromone Composition of a Few Selected Lepidopteran Species," Journal of Asia-Pacific Entomology, vol. 1, no. 1, pp. 17-23, 1998.

[12] K. S. Boo and J. W. Park, "Sex Pheromone Composition of the Asian Corn Borer Moth, Ostrinia furnacalis (Guenée) (Lepidoptera: Pyralidae) in South Korea," Journal of Asia-Pacific Entomology, vol. 1, no. 1, pp. 77-84, 1998.

[13] W. Liu, P. Yang, L. Jiang et al., "Progress on sex pheromones synthesis of Asian corn borer: Ostrinia furnacalis (Guenée)," Agricultural Science Technology, vol. 14, pp. 1842-1846, 2013.

[14] S. K. Kang, J. M. Park, and K. L. Hwang, "Synthesis and biological test of the pheromone of the Asian corn borer moth (Ostrinia furnacalis)," Bulletin of the Korean Chemical Society, vol. 6, pp. 15-19, 1985.

[15] J. W. Chen, J. X. Huang, J. L. Jiang, Y. M. Wu, and Z. X. Jiang, "Expanding synthesis and side effect of the sex pheromone of Asian corn borer," Journal of Hubei University: (Natural Science), vol. 13, pp. 140-146, 1991.

[16] J. W. Chen, J. L. Jiang, and J. Lu, "The improved synthesis of the sex pheromone of Asian corn borer," Chinese Journal of Organic Chemistry, vol. 9, pp. 80-83, 1989.

[17] H. B. Chen and Y. J. Du, "Convenient synthesis of the sex pheromone of Asian corn borer," Chinese Journal of Pesticide Science, vol. 12, pp. 90-92, 2010.

[18] J. M. Li, J. P. Yong, F. L. Huang, S. Z. Bai, T. M. Xiao, and H. Y. Chen, "A convenient synthesis of the sex pheromone of Ostrinia Orientalis," Modern Agrochemicals, vol. 10, pp. 35-37, 2011.

[19] Z. M. Li and M. Schwarz, "A convenient synthetic route for the sex pheromone of the Asian corn borer moth Ostrinia furnacalis (Guenée)," Science China, vol. 7, pp. 679-686, 1984.

[20] Y. C. Wang and F. C. Liu, "Improvement synthesis of the sex pheromone of Asian corn borer," Journal of Kunming Junior Normal College (Natural Science), vol. 9, pp. 90-94, 1994.

[21] F. C. Liu, J. Lin, and Y. C. Wang, "A convenient synthesis of the sex pheromone of Ostrinia furnacalis (Guenée)," Organic Chemistry, vol. 15, pp. 546-549, 1995.

[22] R. Kou, H. Y. Ho, H. T. Yang, Y. S. Chow, and H. J. Wu, "Investigation of sex pheromone components of female asian corn borer, Ostrinia furnacalis (Hübner) (Lepidoptera: Pyralidae) in Taiwan," Journal of Chemical Ecology, vol. 18, no. 6, pp. 833-840, 1992.

[23] D. Schneider, "Elektrophysiologische Untersuchungen von Chemo- und Mechanorezeptoren der Antenne des Seidenspinners Bombyx mori L."' Zeitschrift für Vergleichende Physiologie, vol. 40, no. 1, pp. 8-41, 1957.

[24] Z.-Q. Cheng, J.-C. Xiao, X.-T. Huang et al., "Sex pheromone components isolated from china corn borer, Ostrinia furnacalis guenée (lepidoptera: Pyralidae), (E)- and (Z)-12-tetradecenyl 
acetates," Journal of Chemical Ecology, vol. 7, no. 5, pp. 841-851, 1981.

[25] J. W. Du, Y. X. Zhu, T. P. Zhang et al., "Studies on the precise blending of the pheromone components of the Asian corn borer Ostrinia furnacalis Guenée (Lep: Pyralidae)," Contributions from Shanghai Institute of Entomology, pp. 17-22, 2015.

[26] S. F. Yeh, K. C. Lee, K.-T. Chang, F.-C. Yen, and J.-S. Hwang, "Sex pheromone components from asian corn borer, Ostrinia furnacalis (Hubner) (Lepidoptera: Pyralidae) in Taiwan," Journal of Chemical Ecology, vol. 15, no. 2, pp. 497-505, 1989.

[27] T. Ando, K. Arai, N. Takahashi, and O. Saito, "(Z) and (E)-12Tetradecenyl Acetates: Sex Pheromone Components of Oriental Corn Borer (Lepidoptera: Pyralidae)," Agricultural and Biological Chemistry, vol. 44, no. 11, pp. 2643-2649, 1980.

[28] H. Zhou and J. W. Du, "Behavioural effect of various binary and ternary sex pheromone blends on the Asian Corn Borer (Ostrinza furnacalis)," Entomologia Sinica, vol. 6, pp. 336-344, 1999.

[29] S. B. Olsson and B. S. Hansson, "Electroantennogram and single sensillum recording in insect antennae," Methods in Molecular Biology, vol. 1068, pp. 157-177, 2013.

[30] Y. Q. Sun, Functional study on pheromone binding proteins of Ostrinia furnacalis (Guenée), [M.S., thesis], Shenyang Agricultural University, Shenyang, China, 2016. 

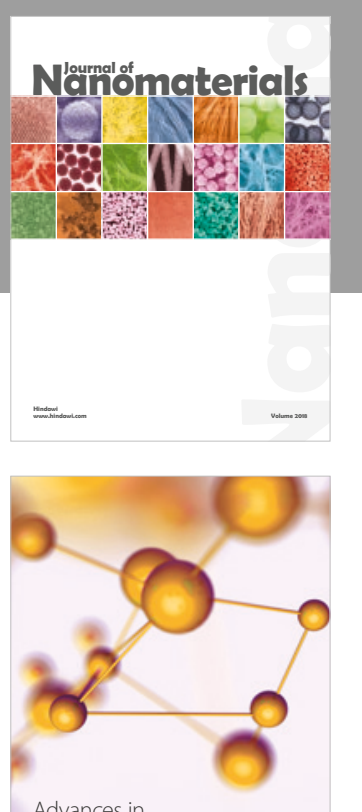

Physical Chemistry
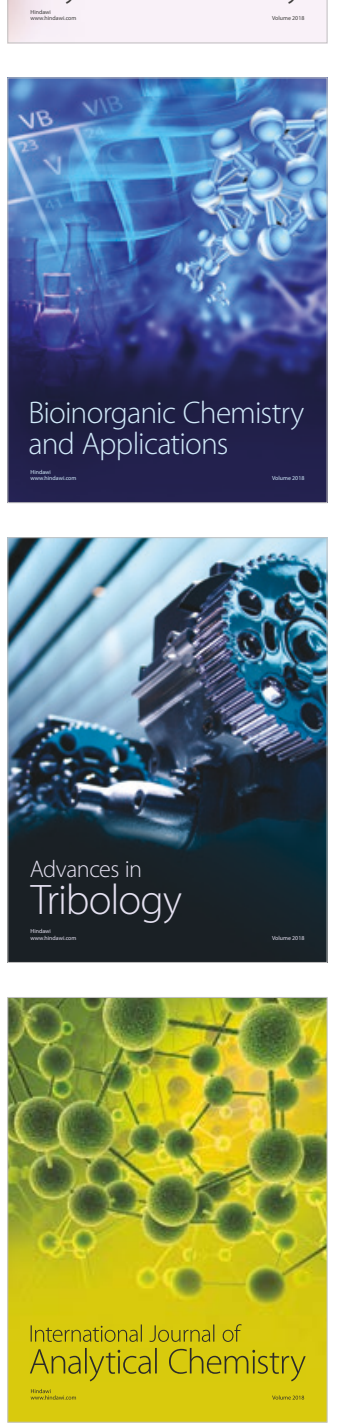

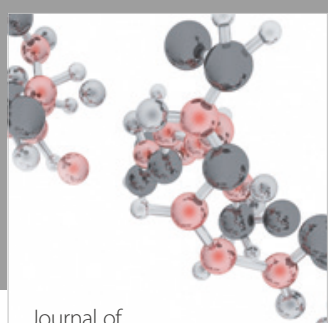

Analytical Methods

in Chemistry

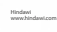

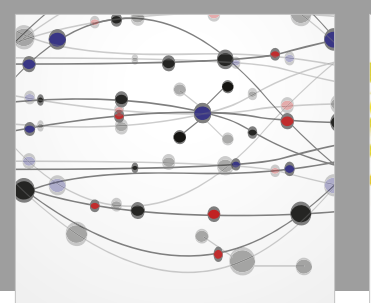

The Scientific World Journal

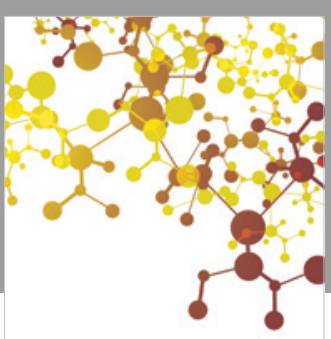

Journal of

Applied Chemistry
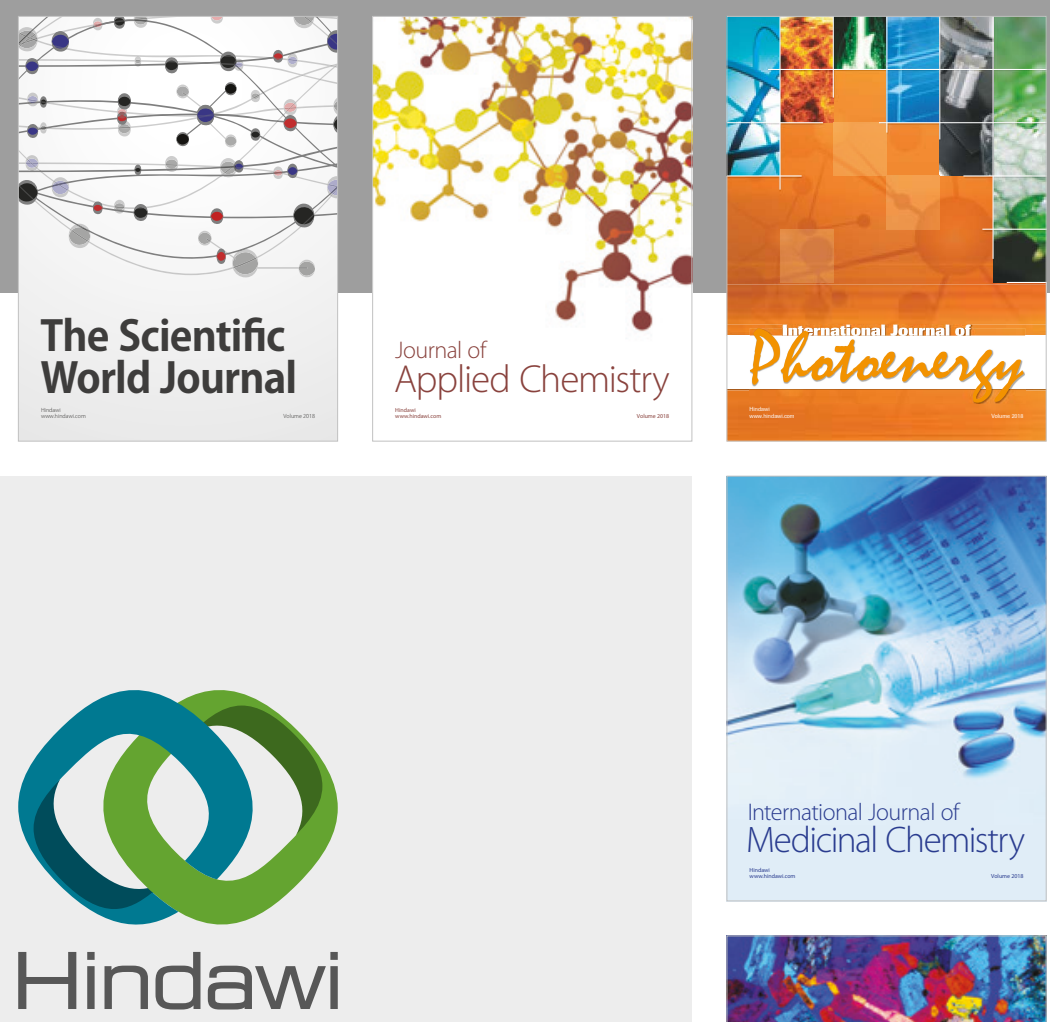

Submit your manuscripts at

www.hindawi.com
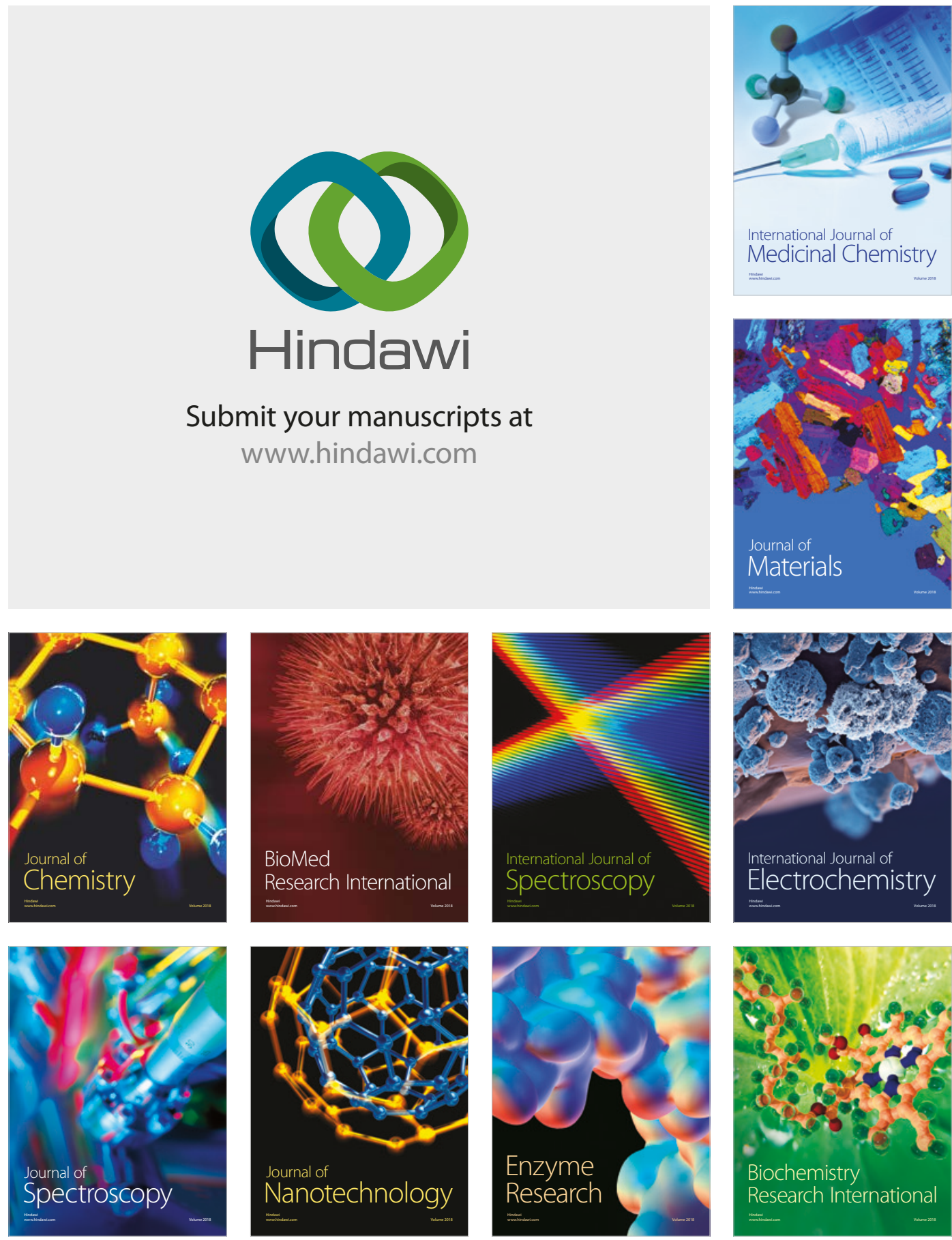
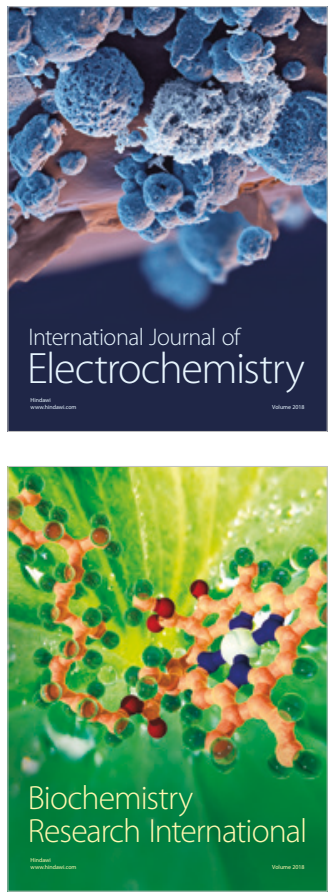